\title{
Influence of ripening time on the amount of certain biogenic amines in rind and core of cow milk Livno cheese
}

\author{
doi: 10.15567/mljekarstvo.2014.0303 \\ Antonela Marijan ${ }^{1}$, Petar Džaja ${ }^{2}$, Tanja Bogdanović ${ }^{1}$, Ines Škoko ${ }^{1}$, \\ Željko Cvetnić ${ }^{1}$, Vesna Dobranić ${ }^{3}$, Nevijo Zdolec ${ }^{3}$, Edin Satrović $^{4}$, Krešimir Severin ${ }^{2}$ * \\ ${ }^{1}$ Croatian Veterinary Institute, Savska cesta 143, 10000 Zagreb, Croatia \\ ${ }^{2}$ Department of Forensic and State Veterinary Medicine, ${ }^{3}$ Department of Hygiene, Technology and Food \\ Safety, Veterinary Faculty University of Zagreb, Heinzelova 55, 10000 Zagreb, Croatia \\ ${ }^{4}$ Department of State and Forensic Veterinary Medicine, Veterinary Faculty Sarajevo, \\ Zmaja od Bosne 90, 71000 Sarajevo, Bosnia and Herzegovina \\ Received - Prispjelo: 25.03.2014. \\ Accepted - Prihvaćeno: 15.07.2014.
}

\begin{abstract}
Determining the levels of biogenic amines in cheese except that it has significance for determining the nutritional value and hygienic accuracy, cheese as food can be used as a parameter to evaluate the conditions of production and/or ripening of products, and particularly in the selection of bacterial cultures. The purpose of this paper was to determine the effect of the ripening process on the amount of biogenic amines in cheese. For this purpose were conducted physico-chemical analysis, determination of biogenic amines and microbiological analysis. During the process of ripening Livno cheese from three different batches was taken one cheese from prime day and $9^{\text {th }}, 20^{\text {th }}, 29^{\text {th }}, 50^{\text {th }}$, $60^{\text {th }}$ and $105^{\text {th }}$ day. From each cheese two samples were taken, one from the middle and one from the cheese rind. During $105^{\text {th }}$ day of ripening Livno cheese, the presence of triptamin, ß-feniletlamine, putrescine, cadaverine, histamine, tyramine, spermine and spermidine were determinated. The maximum total values of searched biogenic amines were found $105^{\text {th }}$ day, in the middle 184.13 $\mathrm{mg} / \mathrm{kg}$ and $76.26 \mathrm{mg} / \mathrm{kg}$ in the rind of cheese. With an indication that the largest share of value represent histamine with $43.9 \%$ and tyramine with $38.2 \%$ in the middle, respectively histamine with $31.6 \%$ and tyramine with $31.5 \%$ in the rind of cheese. The values of putrescine and spermine were in small ranges and they are not identified in all samples. The values of histamine and tyramine are almost a third more at $105^{\text {th }}$ than $60^{\text {th }}$ day. There was a significant difference between the middle and the rind of cheese in the values of biogenic amines. Correlation between biogenic amines and microorganisms has not been determined.
\end{abstract}

Key words: ripening cheese, biogenic amines, Livno cheese

\section{Introduction}

The cheese is a type of fermented food which can be associated with the formation of biogenic amines during the production, ripening and storage (Valsamaki et al., 2000). Known factors which affect the formation of biogenic amines are $\mathrm{pH}$, salt concentration, bacterial activity, humidity, storage temperature, ripening time and microorganism synergy. A crucial factor for the formation of biogenic amines in cheese is the presence of microorganisms with decarboxylase activity (Linares et al., 2011). It is well known that the bacteria from the genus Enterococcus and Lactobacillus are mostly responsible for the production of biogenic amines in cheeses made from raw milk (Burdychova and Komprda, 2007; Ladero et al., 2012).

Determining the levels of biogenic amines in cheese is significant for determining the hygienic conditions of production and/or ripening, and particularly 
in the selection of bacterial cultures (Moret et al., 1996).

Some researchers showed that the presence of specific bacteria can cause the presence of certain biogenic amines (Celano et al., 1996; Petridis and Steinhart, 1996a) but, other consider that relationship between microorganism and biogenic amines is not notable (Öner et al., 2006). On the other hand, besides the prerequisites of production hygiene, some lactic acid bacteria that are essential and acceptable according to health-based and technological standards can be used for the reduction of the amount of biogenic amines in cheese (Ladero et al., 2009). During cheese ripening the amount of biogenic amines increases according to the progression of proteolytic changes (Galgano et al., 2001; Ladero et al., 2010a). It is known that during the ripening of hard cheeses the amount of free amino acids and peptides increases (Radeljević et al., 2013). Džaja et al. (2005) in Livno cheese (hard cheese, Hercegovina) perceived the biggest average amount of histamine at the end of the ripening process $(14.4 \mathrm{mg} / \mathrm{kg}$ in cheese rind, $12.4 \mathrm{mg} / \mathrm{kg}$ in the cheese core).

Since the highest acceptable amount of biogenic amines is regulated only for histamine in fish, and in the endeavor to regulate the highest amount of biogenic amines in other animal products, the main goal of this study was to determine the amount of specific biogenic amines in hard cheese (Livno cheese) with extended ripening time (105 days instead of the standard 60 days). Moreover, this paper studies the changes of the amount of biogenic amines during the ripening process and the relation between biogenic amines in the middle and in the cheese rind.

\section{Material and methods}

\section{Cheese making technology and sampling}

Raw cow milk for cheese production from the collecting areas was delivered to the cheese dairy in Livno. Before dispensing and storage in silo cistern, milk samples were taken for analysis of chemical, textural, density, acidity and microbiological parameters. Before the expansion the milk was pasteurized on the plate pasteurizer by heating to $72-74{ }^{\circ} \mathrm{C}$ for 40 seconds and bactofugated on $50-55^{\circ} \mathrm{C}$. Processed milk was typified with a separator on $3.5 \%$ milk fat, cooled to $2-6{ }^{\circ} \mathrm{C}$ and stored. The milk which was ready for expansion was taken to a cheese making vat where starter (1 U/100 L milk), calcium chloride and potassium nitrate $(0.02 \%)$, annatto colorant $(80 \mathrm{~mL})$ and chymosin rennet were added.

The curdling process lasted for 45 minutes with a constant temperature of $30{ }^{\circ} \mathrm{C} \pm 1{ }^{\circ} \mathrm{C}$ after which the curd has been cut to produce granules the size of wheat grains. During the formation of cheese curd a quarter of the whey was separated, after which, with constant mixing, the same amount of technological water was added. Releasing the vapor along the cloak thin mass, whey, water and cheese bean were heated to $46-48{ }^{\circ} \mathrm{C}$ for 30 minutes, that is, until the anticipated toughness was achieved and dry cheese bean was formed. The cheese curd and whey mass was then placed in a press and the cheese mass was molded into the cheese dimension. The cheese was then wrapped in cheese cloth, placed in molds and pressed for about $20 \mathrm{~h}$. After that, the pressed cheese was placed in palettes made of stainless steel and submerged into a brine bath for 3-4 days. The concentration of salt of the washing brine was $25 \%$ of table salt and the temperature of the washing brine was between $13^{\circ} \mathrm{C}$ and $17^{\circ} \mathrm{C}$. After removing it from the washing brine, the cheese was drained with a colander and dried for $24 \mathrm{~h}$ in a room where the temperature was $18{ }^{\circ} \mathrm{C}$. Finally, the cheese was taken to a ripening room where it was placed on wooden shelves. The temperature of the ripening room was around $15-18{ }^{\circ} \mathrm{C}$ and the humidity was $80-85 \%$. During the 60 days of ripening the cheese was rotated, in the first days of ripening 2 times per week and until the end of the ripening process once per week.

During the ripening of Livno cheese one cheese was taken from three different batches on day zero and on the $9^{\text {th }}, 20^{\text {th }}, 29^{\text {th }}, 50^{\text {th }}$ and $60^{\text {th }}$ day. Three cheeses from different batches were stored under the same above described ripening conditions until the $105^{\text {th }}$ day. Two samples were taken from each cheese, one from the middle (Uzl) and one from the cheese rind (Uz2). Altogether, 42 samples were collected; 21 from the middle and 21 from the cheese rind.

\section{Physicochemical analysis}

Total lipid extraction from the samples was determined using a method according to Folch (Folch et al., 1957). Raw proteins content was determined 
according to Kjeldahl method - with the use of digestion block (Kjedatherm KB, Gerhardt) and automatic distillation and titration mechanism (Vapodest 50, Gerhardt) according to the standards of AOAC methods (AOAC, 2000b). The content of dry matter was determined by gravimetric method ISO 5534 (2004). The salt content was determined by Mohr's method (AOAC, 2000a). The fat in dry matter was calculated according to the following equation: [fat (\%) / dry matter (\%)] x 100. The value of cheese $\mathrm{pH}$ was measured with digital $\mathrm{pH}$ meter (702 SET/MET Titrino) directly from the cheese samples homogenized and distilled with water in 1:1 ratio. Water activity $\left(\mathrm{a}_{\mathrm{w}}\right)$ in cheeses was determined using an $\mathrm{a}_{\mathrm{w}}$ meter Rotronic AG, HygroPalm AWlset 40 .

\section{Determination of biogenic amines}

Biogenic amines triptamin (TRP), ß-feniletlamine ( $\beta$ PHE), putrescine (PUT), cadaverine (CAD), histamine (HIS), tyramine (TYR), spermidine (SPD) and spermine (SPM) were analyzed by high-performance liquid chromatography (Eerola et al., 1993; Martusceli et al., 2005). A pre-column derivatization procedure using dansyl chloride was applied. Identification and quantification were done by comparison with specific standards (Sigma) through calibration curves.

For pre-column derivatization the extraction procedure of Eerola et al. (1993) was used with a modification of the ratio between cheese and $0.4 \mathrm{~mol} / \mathrm{L}$ of $\mathrm{HClO}_{4}$. In brief, $125 \mathrm{~mL}$ of an internal standard solution (1.7 heptanediamine, SigmaAldrich, St. Louis, MO, USA) and $15 \mathrm{~mL} 0.4 \mathrm{~mol} / \mathrm{L}$ $\mathrm{HClO} 4$ were added to $2.0 \mathrm{~g}$ of cheese prior to homogenization for 1 min using an Ultra Turrax T25 (IKA-Labortechnik, Staufen, Germany). The homogenate was centrifuged (10 $\mathrm{min}, 2250 \mathrm{~g}$ ) and the supernatant filtered through a $0.45 \mathrm{~mm}$ filter. 1.00 $\mathrm{mL}$ of filtered cheese extract or BA solutions was alkalized by adding $200 \mathrm{~mL}$ of $\mathrm{NaOH}$ solution (2 $\mathrm{mol} / \mathrm{L}$ ) and $300 \mathrm{~mL}$ of saturated $\mathrm{NaHCO}_{3}$ solution. Derivatization was obtained by thoroughly mixing with $1.00 \mathrm{~mL}$ of dansyl chloride (Sigma-Aldrich, St. Louis, MO, USA) solution in acetone $(10 \mathrm{mg} /$ $\mathrm{mL}$ ) followed by incubation $\left(45 \mathrm{~min}\right.$ at $\left.40{ }^{\circ} \mathrm{C}\right) .150$ $\mathrm{mL}$ of $\mathrm{NH}_{4} \mathrm{OH}$ solution $(1 \mathrm{~mol} / \mathrm{L})$ was then added to remove excess dansyl chloride and the solution was kept in dark for $30 \mathrm{~min}$. Acetonitrile was added to a total volume of $5.00 \mathrm{~mL}$, followed by filtration using $0.45 \mathrm{~mm}$ PTFE filter $(25 \mathrm{~mm} * 0.45 \mu \mathrm{m}$ (Cronus). The HPLC analyses were carried out using a classical Agilent 1200 Series LC system (Agilent Technologies Inc., Waldbronn, Germany) equipped with degasser, binary pump, auto sampler, column oven, diode array (UV) detector (set at $254 \mathrm{~nm}$ ). The column was $4.0 \mathrm{~mm}$ x $250 \mathrm{~mm}$ x $5 \mu \mathrm{m}$ C 18 column (LiChrospher, phenomenex) and the mobile phase was $0.1 \mathrm{~mol} / \mathrm{L}$ ammonium acetate/acetonitrile in gradient mode at a flow rate $1.0 \mathrm{~mL} / \mathrm{min}$ with the column oven set at $40^{\circ} \mathrm{C}$ (Eerola et al., 1993).

\section{Microbiological analysis}

Test sample (10 g) was weighted in sterile plastic bag. $90 \mathrm{~mL}$ of buffered peptone solution was added and homogenized in homogenizer Bagmixer 400 (Interscience, France) for 2 minutes. Serial decimal dilution was prepared in Maximum Recovery Diluent (MRD; Biolife, Milano, Italy), and grafted in triplicate on the corresponding culture medium.

The count of aerobic mesophilic bacteria was determined following HRN ISO/ 4833:2003 method and using Plate Count Agar (PCA, Biolife, Italy); coagulase positive staphylococci by HRN EN ISO/6888-1:2004 on Baird Parker agar (Biolife, Italy); yeasts and molds by ISO/ 21527-2:2008 on Rose Bengal Agar (Bilife, Italy); Pseudomonas spp. by HRN ISO/13720:1999) on Pseudomonas selective agar (Biolife, Italy) and Enterococcus spp. were determined on Slanetz- Bartley Agar (SBA, Biolife, Italy) at $37^{\circ} \mathrm{C}$ for $24 \pm 2 \mathrm{~h}$. The presence of Salmonella spp. and Listeria monocytogenes was determined according to HRN EN ISO/ 6579:2003 and HRN EN ISO 11290-1:1999.

\section{Statistical analysis of data}

The data were analyzed with computer program STATISTICA (data analysis software system), StatSoft, Inc. (2011), version 10. www.statsoft. com. Basic statistical analysis of the observed results was done with usual methods of descriptive statistic, with the determination of arithmetic mean ( $\mathrm{x}$ ), standard deviation (s), minimum (min) and maximum values (max). Verification normality of data allocation was determined with Kolmogorov-Smirnov test. Depending on the results of Kolmogor-Smirn 


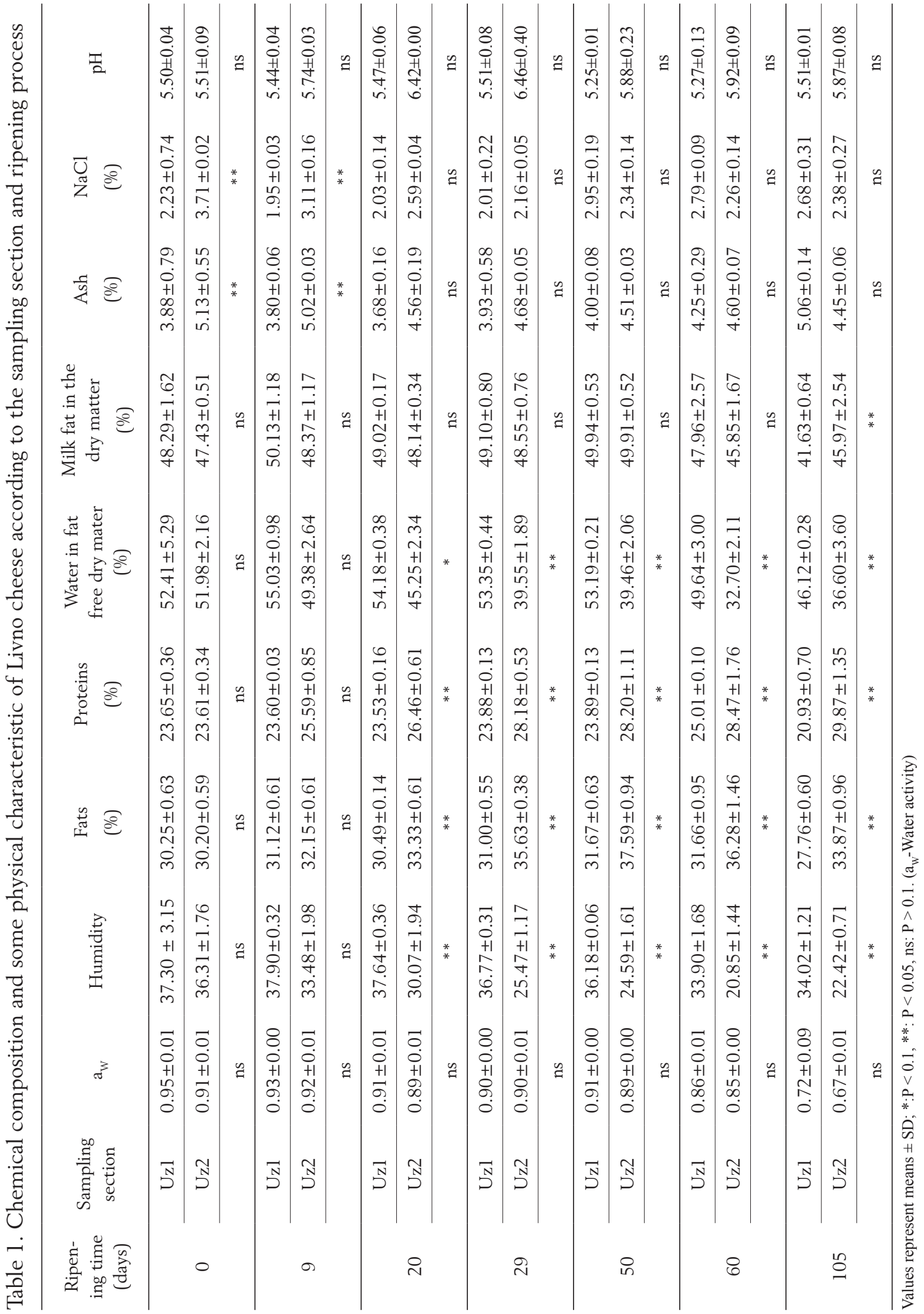


test one-way analysis of variance was implemented (one-way ANOVA) or Kruskal-Wallis analysis of variance. Statistical hypothesis was tested on the level of significance $\mathrm{p}=0.05$ respectively, the differences were significant only if $\mathrm{p}<0.05$ correlation between individual values and the cheese ripening was determined with Person's correlation coefficient.

\section{Results}

\section{Chemical composition and physical characteristic of Livno cheese}

Basic chemical characteristic and some physical characteristic of Livno cheese according to the sampling section and ripening process are shown in the Table 1. During the 105 days of the ripening process of Livno cheese the values of water activity were recorded and statistically significant difference was not observed $(\mathrm{P}<0.05)$ between samples that were taken from the middle (Uzl) and from the cheese rind (Uz2). The values ranged from 0.95 to 0.72 in the middle and from 0.91 to 0.67 in the cheese rind during the ripening process.

Apart from the water activity, the differences of humidity, fat, proteins and water content in the fat dry free matter were determined between the sampling sections and those values were statistically significant $(\mathrm{P}<0.01)$ from the $20^{\text {th }}$ day of ripening until the $105^{\text {th }}$ day. The average humidity content during the ripening was gradually decreasing from $37.30 \%$ to $34.02 \%$ in the middle and from $36.31 \%$ to $22.42 \%$ in the cheese rind during the ripening period. Significant negative correlation was determined between humidity content and the duration of ripening in the middle $(-0.69$, $\mathrm{P}<0.01)$ and in the cheese rind $(-0.82, \mathrm{P}<0.01)$. Furthermore, the fat percentage was increasing progressively until the $60^{\text {th }}$ day in the middle (from 30.25 $\%$ to $31.66 \%$ ) and until the $50^{\text {th }}$ day in the cheese rind (from $30.20 \%$ to $36.28 \%$ ), while on the $105^{\text {th }}$ day a significant $(\mathrm{P}<0.05)$ decrease was recorded to $27.76 \%$ in the middle and $33.87 \%$ in the cheese rind.

A change in the percentage of proteins and fats was also recorded with an increase of value in the cheese rind from the starting value of $23.61 \%$ to $29.87 \%$ on the $105^{\text {th }}$ day, while in the middle the increase was recorded until the $60^{\text {th }}$ day from $23.65 \%$ to $25.01 \%$ and significant decrease to $20.93 \%(\mathrm{P}<0.05)$ was recorded on the $105^{\text {th }}$ day of measuring. The water content in fat free substance has changed from $52.41 \%$ to $46.12 \%$ in the middle, and from $51.98 \%$ to $36.60 \%$ in cheese rind, which confirms a negative correlation coefficient $-0.72, \mathrm{P}<0.01$ and $-0.78, \mathrm{P}<0.01$. Regarding the milk fat in the dry matter, according to the sampling section, statistical significance $(\mathrm{P}<0.05)$ was determined only on the $105^{\text {th }}$ day. On the other hand, significant differences $(\mathrm{P}<0.05)$ in the amount of ash were determined only on day zero and the $9^{\text {th }}$ day of sampling. In the content of $\mathrm{NaCl}$ a significant difference $(\mathrm{P}<0.05)$ was determined the only on day zero and the $9^{\text {th }}$ day according to the sampling section and the highest values were determined in the cheese rind (3.71 $\%$ on day zero and $3.11 \%$ on the $9^{\text {th }}$ day). Finally, the $\mathrm{pH}$ values in the cheese were 5.51 to 6.46 in the cheese rind, and 5.25 to 5.51 in the middle, but statistically significant differences $(\mathrm{P}<0.05)$ were not determined between the middle and the cheese rind.

\section{Microbiological analysis of Livno cheese}

In this research the presence and succession of the following microorganisms during the ripening process of Livno cheese were observed: Salmonella spp., L. monocytogenes, aerobic mesophilic bacteria, coagulase positive staphylococci, Enterococcus spp., Pseudomonas and yeast and moulds. The count of microorganisms which were studied according to the sampling section and ripening process is shown in Table 2. During the cheese ripening statistically significant difference was determined $(\mathrm{P}<0.05)$ only in the number of yeast on the $105^{\text {th }}$ day according to the sampling section. Also, negative correlations were determined between the number of aerobic mesophilic bacteria $(-0.45, \mathrm{P}<0.05)$ during the ripening process next to the cheese rind. Salmonella spp., L. monocytogenes, coagulase positive staphylococci, moulds and Pseudomonas spp. were not identified in any of the investigated samples of cheese.

\section{The results of biogenic amines}

The content of biogenic amines in Livno cheese according to the sampling section and duration of the ripening process is shown in Table 3. During the 105 days of ripening process in Livno cheese the presence of $ß$-feniletlamine, putrescine, cadaverine, histamine, tyramine, spermine and spermidine were 
Table 2. The count of microorganisms according to the sampling section and ripening process

\begin{tabular}{|c|c|c|c|c|c|}
\hline \multirow{2}{*}{$\begin{array}{l}\text { Ripening time } \\
\text { (days) }\end{array}$} & \multirow{2}{*}{$\begin{array}{l}\text { Sampling } \\
\text { section }\end{array}$} & \multicolumn{4}{|c|}{ Microorganisms $\left(\log _{10} \mathrm{cfu} / \mathrm{g}\right)$} \\
\hline & & $\begin{array}{c}\text { Aerobic mesophilic } \\
\text { bacteria }\end{array}$ & $\begin{array}{l}\text { Coagulase positive } \\
\text { staphylococci }\end{array}$ & $\begin{array}{l}\text { Enterococcus } \\
\text { spp. }\end{array}$ & Yeast \\
\hline \multirow{3}{*}{0} & Uzl & $6.25 \pm 0.22$ & $<2$ & $3.22 \pm 0.52$ & $0.68 \pm 0.59$ \\
\hline & Uz2 & $6.06 \pm 0.08$ & $<2$ & $3.21 \pm 0.47$ & $<2$ \\
\hline & & ns & & ns & ns \\
\hline \multirow{3}{*}{9} & Uzl & $7.31 \pm 0.23$ & $<2$ & $3.60 \pm 0.20$ & $1.06 \pm 0.06$ \\
\hline & Uz2 & $7.69 \pm 0.21$ & $<2$ & $3.36 \pm 0.23$ & $1.68 \pm 0.68$ \\
\hline & & ns & & ns & ns \\
\hline \multirow{3}{*}{20} & Uzl & $7.26 \pm 0.54$ & $<2$ & $3.96 \pm 0.58$ & $0.75 \pm 0.66$ \\
\hline & Uz2 & $7.54 \pm 0.34$ & $<2$ & $3.87 \pm 0.20$ & $1.97 \pm 0.46$ \\
\hline & & ns & & ns & ns \\
\hline \multirow{3}{*}{29} & Uzl & $7.09 \pm 0.10$ & $<2$ & $2.12 \pm 0.22$ & $0.68 \pm 0.59$ \\
\hline & Uz2 & $7.55 \pm 0.04$ & $<2$ & $2.24 \pm 0.32$ & $2.25 \pm 0.10$ \\
\hline & & ns & & ns & ns \\
\hline \multirow{3}{*}{50} & Uzl & $6.99 \pm 0.18$ & $<2$ & $2.73 \pm 0.15$ & $<2$ \\
\hline & Uz2 & $7.37 \pm 0.19$ & $<2$ & $3.85 \pm 0.09$ & $1.66 \pm 0.64$ \\
\hline & & ns & & ns & ns \\
\hline \multirow{3}{*}{60} & Uzl & $7.07 \pm 0.50$ & $<2$ & $3.14 \pm 0.23$ & $0.34 \pm 0.59$ \\
\hline & Uz2 & $6.96 \pm 0.34$ & $<2$ & $3.46 \pm 0.15$ & $1.77 \pm 0.51$ \\
\hline & & ns & & ns & ns \\
\hline \multirow{3}{*}{105} & Uzl & $6.88 \pm 0.03$ & $<2$ & $2.59 \pm 0.07$ & $0.33 \pm 0.58$ \\
\hline & Uz2 & $4.32 \pm 3.79$ & $<2$ & $2.12 \pm 1.87$ & $2.77 \pm 1.34$ \\
\hline & & ns & & ns & $* *$ \\
\hline
\end{tabular}

Values represent means $\pm \mathrm{SD}{ }^{*}: \mathrm{P}<0.1,{ }^{* *}: \mathrm{P}<0.05$, ns: $\mathrm{P}>0.1$

determined. Triptamin was not determined in any samples. Also, putrescine was identified only in samples which were taken from the middle, as opposed to spermine which was not determined in those samples. Changes in biogenic amine concentrations in the middle and in the cheese rind during the ripening process of cheese are shown in Figure 1. Maximum total values of the examined biogenic amines were determined and on the $105^{\text {th }}$ day their amount was $184.13 \mathrm{mg} / \mathrm{kg}$ in the middle, and $76.26 \mathrm{mg} / \mathrm{kg}$ in the cheese rind. It should be noted that histamine had the largest content among biogenic amines with $43.9 \%$ and the content of tyramine was $38.2 \%$ in the middle, while the content of histamine was 31.6 $\%$ and tyramine $31.5 \%$ in the cheese rind. The re- sults of this research showed the presence of histamine from day zero in values from $0.13 \mathrm{mg} / \mathrm{kg}$ in the cheese rind and from $4.33 \mathrm{mg} / \mathrm{kg}$ in the middle, to $24.10 \mathrm{mg} / \mathrm{kg}$ in the cheese rind to $80.97 \mathrm{mg} / \mathrm{kg}$ in the middle on the $105^{\text {th }}$ day. Constant increase of the values of histamine according to the duration of ripening process confirms a high positive correlation coefficient in the middle $(0.96, \mathrm{P}<0.05)$ and in the cheese rind $(0.83, \mathrm{P}<0.05)$. Statistically significant differences $(\mathrm{P}<0.01)$ between the sampling section were determined from the $9^{\text {th }}$ day until the last day of ripening. The next biogenic amines regarding the total content was tyramin which was present in all of the samples taken from the middle as opposed to the samples taken from the cheese rind on zero, the 
$9^{\text {th }}, 20^{\text {th }}$ and $29^{\text {th }}$ day where it was not determined. The highest values were determined on the last day in the middle; $70.41 \mathrm{mg} / \mathrm{kg}$ and in the cheese rind $24.03 \mathrm{mg} / \mathrm{kg}$. According to the sampling section, significant differences $(\mathrm{P}<0.05)$ in the values were determined on the $60^{\text {th }}$ and the $105^{\text {th }}$ day from the begging of ripening process. Spermidine was determined in all of the samples in the cheese rind, as opposed to the samples taken from the middle where it was not determined on the $20^{\text {th }}, 29^{\text {th }}$ and $50^{\text {th }}$ day. Significant increase of values of spermine $(\mathrm{P}<0.05)$ was determined in the cheese rind from the $50^{\text {th }}$ until the last day of ripening. Also, in those periods statistically significant differences were determined according to the sampling section, in the middle and in the cheese rind. The values of cadaverine have changed from $1.26 \mathrm{mg} / \mathrm{kg}$ on day zero to $9.8 \mathrm{mg} /$ $\mathrm{kg}$ on the $105^{\text {th }}$ day in the middle of cheese and from $0.93 \mathrm{mg} / \mathrm{kg}$ on the $9^{\text {th }}$ day to $5.27 \mathrm{mg} / \mathrm{kg}$ on the $105^{\text {th }}$ day in the cheese rind. Significant differences between the samples from the middle and the cheese rind were determined on the $50^{\text {th }}(\mathrm{P}<0.05)$ and the $60^{\text {th }}$ day. -feniletlamin was determined on the $50^{\text {th }}$ day in the middle $(5.02 \mathrm{mg} / \mathrm{kg})$ and in the cheese rind $(1.06 \mathrm{mg} / \mathrm{kg})$. The values have significantly increased $(\mathrm{P}<0.05)$ on the $105^{\text {th }}$ day when a significant difference $(\mathrm{P}<0.01)$ was determined between the samples from the middle and the cheese rind. The values of the putrescine and spermine have changed in small ranges and were not identified in all of the samples. Putrescine was not identified in any samples which were taken from the cheese rind, as opposed to the spermine which was not identified in any samples taken from the middle.

\section{Discussion}

In this research the total amount of biogenic amines recorded in Livno cheese after 105 days was $184.13 \mathrm{mg} / \mathrm{kg}$ in the middle of cheese and $76.26 \mathrm{mg} /$ $\mathrm{kg}$ in the cheese rind, which is less noticeable than in Feta cheese where after 60 days a total amount of biogenic amines was $330 \mathrm{mg} / \mathrm{kg}$, and after 120 days it was $617 \mathrm{mg} / \mathrm{kg}$ (Valsamaki et al., 2000).

Histamine was recorded in Livno cheese during the whole ripening period (day zero, $9^{\text {th }}, 20^{\text {th }}, 29^{\text {th }}$, $50^{\text {th }}, 60^{\text {th }}$ and $105^{\text {th }}$ day) in the middle and in the cheese rind. Its amount has been progressively increasing during the ripening period and on the $105^{\text {th }}$

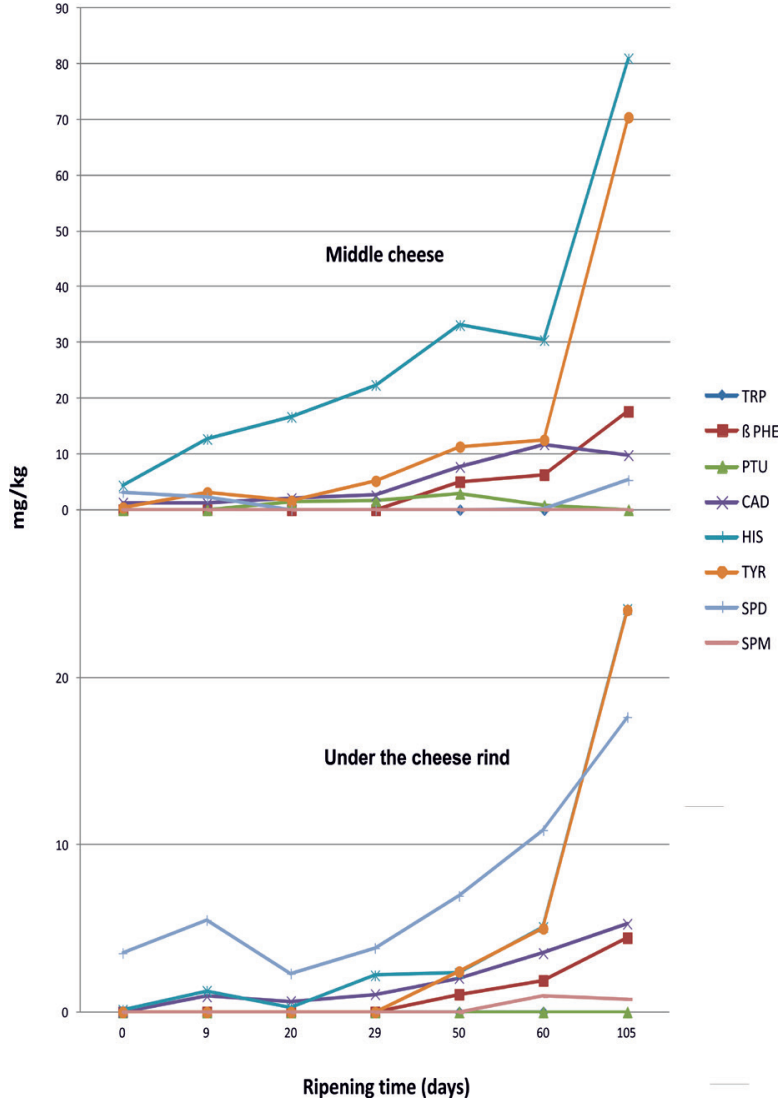

Figure 1. Changes in biogenic amine concentrations in the middle and under the cheese rind during the ripening process of cheese (triptamin - TRP; ß-feniletlamine - $\beta$ PHE; putrescine -PUT; cadaverine -CAD; histamine - HIS; tyramine -TYR; spermidine - SPD and spermine - SPM)

day it was $80.97 \mathrm{mg} / \mathrm{kg}$ in the middle, and 24.10 $\mathrm{mg} / \mathrm{kg}$ in the cheese rind. The amount of histamine increased during the ripening of Semicotto Caprino cheese in which after 60 days of ripening the amount of histamine was $104 \mathrm{mg} / \mathrm{kg}$ while it was not determined on day zero (Galango et al., 2001). The similar increase of histamine during the ripening was detected in Feta cheese when the amount on day zero was $2.4 \mathrm{mg} / \mathrm{kg}$ and on the $120^{\text {th }}$ day it was 84.6 $\mathrm{mg} / \mathrm{kg}$ (Valsamaki et al., 2000). The amount of histamine in all researched periods was always higher in the middle compared to the amount of histamine in the cheese rind, and it was statistically significant $(\mathrm{P}<0.01)$ from the $9^{\text {th }}$ until the last day of ripening. The results of this study are opposite to the results 


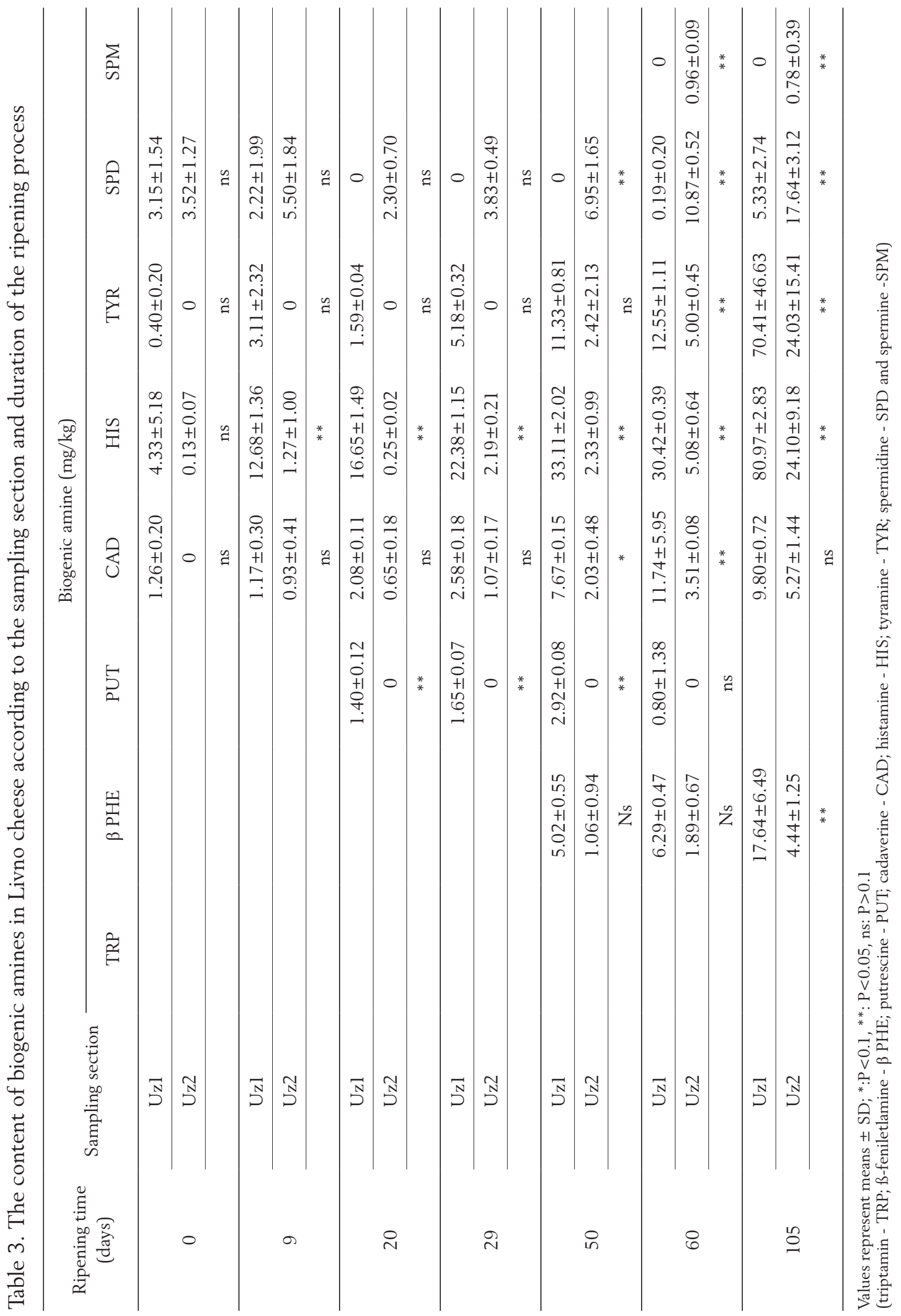


of Petridis and Steinhart (1996a) who reported that the concentration of biogenic amines is increasing through Emmental cheese section to the cheese rind which they explained with better results for the growth of anaerobic and aero tolerant (enterococci, coliforms) bacteria in the outer cheese parts. Moreover, higher amount of histamine in the cheese rind then in the middle was observed by Džaja et al. (2005). The correlation between the amount of histamine and microorganisms (aerobic mesophilic bacteria, coagulase positive staphylococci, Enterococcus spp., Pseudomonas aeruginosa and yeasts) was not determined in this research which corresponds to the results by Öner et al. (2006) in Turkish white cheese. On the other hand, Petridis and Steinhart (1996b) determined a correlation between values of histamine and the number of lactobacilli in Ementaler cheese. Tyramine is detected in all of the samples taken from the middle, as opposed to the samples from the cheese rind in which it was not detected on day zero, the $9^{\text {th }}, 20^{\text {th }}$, and $29^{\text {th }}$ day. The highest amount of tyramine was detected on the $105^{\text {th }}$ day of ripening in the middle $(70.41 \mathrm{mg} / \mathrm{kg})$ and in the cheese rind $(24.03 \mathrm{mg} / \mathrm{kg})$ the amount of tyramine in cheese during the ripening process increased which has also been confirm by other researches. In Feta cheese significantly higher amount of tyramine was detected on the $30^{\text {th }}$ day of ripening $(158 \mathrm{mg} / \mathrm{kg})$, the $90^{\text {th }}$ day of ripening $(204 \mathrm{mg} / \mathrm{kg})$ and the $120^{\text {th }}$ day of ripening (246 mg/kg) (Valsamaki et al., 2000). In comparison, the amount of tyramine was much lower during the ripening of Turkish white cheese, even though it has increased and $12.36 \mathrm{mg} / \mathrm{kg}$ was measured on the $75^{\text {th }}$ day (Öner et al., 2006). As opposed to Petridis and Steinhart (1996b) who detected a close correlation between enterococci in milk and the amount of tyramine, and also between the amount of enterococci and tyramine, research has not shown a correlation between the amount of tyramine and examined microorganisms.

Cadaverine was determined during all ripening periods and its amount increased in the middle and in the cheese rind. The highest amount of cadaverine was detected on the $105^{\text {th }}$ day of ripening, 9.8 $\mathrm{mg} / \mathrm{kg}$ was measured in the middle and $5.27 \mathrm{mg} / \mathrm{kg}$ in the cheese rind. Significant differences between the samples that were taken from the middle and from the cheese rind were detected on the $50^{\text {th }}$ day $(\mathrm{P}<0.05)$ and the $60^{\text {th }}$ day. The results of the in- crease in the amount of cadaverine during ripening period correspond with reports of other authors but in this research the increase was lower. In samples of Caciotta cheese cadaverine was present immediately after adding the salt in cheeses which were made from raw milk and thermally processed milk in five times higher concentration than in homogenized milk. After the $27^{\text {th }}$ day, its concentration was $10 \mathrm{mg} / \mathrm{kg}$ in cheese made from homogenized milk, and in the cheeses made from raw and thermally processed milk concentrations were $24 \mathrm{mg} / \mathrm{kg}$ and $44 \mathrm{mg} / \mathrm{kg}$, respectively (Lanciotti et al., 2007). In semi hard Italian cheese Toma which was made from raw milk, the change from the unheated to heated milk caused an increase of cadaverine concentration from $275 \mathrm{mg} / \mathrm{kg}$ to $440 \mathrm{mg} / \mathrm{kg}$, and when pasteurized milk was used the values were only $69 \mathrm{mg} / \mathrm{kg}$. Cadaverine was present immediately after adding the salt in cheeses made from raw and thermally processed milk in five times higher concentration than in homogenized milk. This concentration was recorded during the all ripening phases. After the $27^{\text {th }}$ day, its concentration was $10 \mathrm{mg} / \mathrm{kg}$ in cheese made from homogenized milk, and in cheese made from raw and thermally processed milk the concentrations were $24 \mathrm{mg} / \mathrm{kg}$ and $44 \mathrm{mg} / \mathrm{kg}$, respectively (Gennaro et al., 2003). In Feta cheese on the $15^{\text {th }}$ day of ripening the amount of cadaverine was 63 $\mathrm{mg} / \mathrm{kg}$ and on the $120^{\text {th }}$ day of ripening it was 82.8 $\mathrm{mg} / \mathrm{kg}$ (Valsamaki et al., 2000).

Spermidine was detected in all samples in the cheese rind as opposed to the samples from the middle where it was not detected on the $20^{\text {th }}, 29^{\text {th }}$ and $50^{\text {th }}$ day of ripening. This biogenic amine, as opposed to other biogenic amines, was detected in higher amount in the cheese rind. Significantly higher increase of values in samples was detected in the cheese rind on the $50^{\text {th }}$ and the $105^{\text {th }}$ day of ripening and significant difference was recorded according to the sampling section.

Tryptamine was not determined in this research, and similar results were obtained by Öner et al. (2006) when tryptamine was determined only on the first day, while Valsamaki et al. (2000) mentioned that it was present in Feta cheese during the whole of the ripening period which was confirmed in the results in all 7 periods of analysis, while higher values were detected on the $60^{\text {th }}$ day of ripening $(7.04 \mathrm{mg} / \mathrm{kg})$. 
ß-feniletilamin was detected only after the $50^{\text {th }}$ day in the middle $(5.02 \mathrm{mg} / \mathrm{kg})$ and in the cheese rind $(1.06 \mathrm{mg} / \mathrm{kg})$, and the amount significantly increased until the $105^{\text {th }}$ day of ripening $(17.64 \mathrm{mg} / \mathrm{kg}$ and $4.44 \mathrm{mg} / \mathrm{kg}$, respectively). In this period a significant difference $(\mathrm{P}<0.01)$ was recorded between the middle and the cheese rind.

Putrescine was not determined in the cheese rind and spermine was not detected in any samples taken from the middle of cheese.

\section{Conclusion}

The amount of histamine after the $60^{\text {th }}$ day of ripening, which is the duration of this process prior to sale, is satisfying in relation to the approved amount of histamine in fish $(100 \mathrm{mg} / \mathrm{kg})$, i.e. the measured amount in the middle was $30.42 \mathrm{mg} / \mathrm{kg}$ and in the cheese rind it was $5.08 \mathrm{mg} / \mathrm{kg}$. Further ripening of Livno cheese until the $105^{\text {th }}$ day significantly increases the amount of histamine and other biogenic amines (tyramine and spermidine). Therefore, since the properties which are characteristic for Livno cheese do not change during the 60 days of ripening, the ripening process should not be extended. The results of this study suggest that the maximum allowed amounts of biogenic amines should be prescribed for all animal products.

\section{Utjecaj trajanja zrenja na količinu pojedinih biogenih amina u sredini $i$ pod korom kravljeg Livanjskog sira}

\section{Sažetak}

Određivanje razine biogenih amina u siru, osim što ima značaj za utvrđivanje higijenske ispravnosti sira, može se upotrijebiti kao parametar za procjenu uvjeta proizvodnje $\mathrm{i} / \mathrm{ili}$ zrenja proizvoda, te posebno u odabiru mljekarskih kultura. U radu se željelo utvrditi utjecaj samog procesa zrenja na količinu biogenih amina u siru. $U$ tu svrhu su obavljene fizikalno-kemijske i mikrobiološke analize, te određivanje sadržaja biogenih amina. Tijekom procesa zrenja Livanjskog sira iz tri različite šarže uzet je po jedan sir i to nultog, 9., 20., 29., 50., 60. i 105. dana. Iz svakog sira uzorkovana su dva uzorka i to iz sredine i pod korom sira. Tijekom 105 dana zrenja Livanjskog sira utvrđena je prisutnosti triptamina, ß-feniletlamina, putrescina, kadaverina, histamina, tiramina, spermina i spermidina. Najveće ukupne vrijednosti pretraživanih biogenih amina utvrđene su 105. dana i to u sredinu $184,13 \mathrm{mg} / \mathrm{kg}$ odnosno 76,26 mg/kg u kori sira. Uz naznaku da najveći udio vrijednosti čini histamin s 43,9 \% i tiramin s 38,2 \% u sredini, odnosno histamin s 31,6 $\%$ i tiramin s 31,5 \% u kori sira. Vrijednosti putrescina i spermina kretale su se $u$ vrlo malim rasponima $i$ nisu utvrđeni u svim uzorcima. Vrijednosti histamina i tiramina su gotovo tri puta više 105. nego 60. dana. Utvrđeno je da postoji značajna razlika između sredine i kore u vrijednostima biogenih amina. Korelacija između biogenih amina i mikroorganizama nije utvrđena.

\section{Ključne riječi: zrenje sira, biogeni amini, Livanjski sir}

\section{References}

1. AOAC (2000a): AOAC official method no. 935.43 Chloride (total) in cheese, 33.7.10. Official methods of analysis (Vol. II, 17th edn.). Gaithersburg, MD, USA: Association of Official Analytical Chemists.

2. AOAC (2000b): Official method no. 920.123 - Nitrogen in cheese, 33.7.12. Official methods of analysis (Vol. II, 17 th edn.). Gaithersburg, MD, USA: Association of Official Analytical Chemists.

3. Burdychova, R., Komprda, T. (2007): Biogenic amine-forming microbial communities in cheese. FEMS Microbiology Letters 276, 149-155. doi: dx.doi.org/10.1111/j.1574-6968.2007.00922.x

4. Celano, G., Cafarchia, C., Tiecco, G. (1996): Formation biogenic amines in pecorino pugliese cheese. Industrie Alimentari 35, 249-252.

5. Džaja, P., Njari, B., Marijan, Ž., Grabarević, Ž., Kipčić, D., Čulina, D., Mihalj. J, (2005): Nalaz histamina u livanjskom siru. Veterinarska stanica 36, 69-73.

6. Eerola, S., Hinkkanen. R., Lindfors, E., Hirvi, T. (1993): Liquid chromatographic determination of biogenic amines in dry sausages. Journal of $A \mathrm{O} A \mathrm{C}$ International 76, 575-577.

7. Folch, J., Lees, M., Sloane Stanley, G.H. (1957): A simple method for isolation and purification of total lipids from animal tissues. Journal of Biological Chemistry 226, 497-509.

8. Galango, F., Suzzi, G., Favati, F., Caruso, M., Matrusceli, M., Gardini, F., Salzano, G. (2001): Biogenic amines during ripening in Semicotto Caprino cheese role of enetrococii. International Journal of Food Science and Technology 36, 153-160. doi: dx.doi.org/10.1046/j.1365-2621.2001.00443.x 
9. Gennaro, Mc., Gianotti, V., Marengo, E., Pattono, D., Turi, R.M. (2003): A chemometric investigation of the effect of the cheese-making process on contents of biogenic amines in a semi-hard Italian cheese (Toma). Food Chemistry 82, 545-551.

10. HRN EN ISO 11290-1 (1999): Mikrobiologija hrane i stočne hrane - Horizontalna metoda za dokazivanje i određivanje broja stanica Listeria monocytogenes, Hrvatski zavod za norme, Zagreb.

11. HRN ISO 13720 (1999): Meso i mesni proizvodi - Brojenje Pseudomonas spp., Hrvatski zavod za norme, Zagreb.

12. HRN ISO 4833 (2003): Mikrobiologija hrane i stočne hrane. Horizontalna metoda za brojenje mikroorganizama - Tehnika brojenja kolonija na $30^{\circ} \mathrm{C}$, Hrvatski zavod za norme, Zagreb.

13. HRN EN ISO 6579 (2003): Mikrobiologija hrane i stočne hrane - Horizontalna metoda za otkrivanje Salmonella spp., Hrvatski zavod za norme, Zagreb.

14. HRN EN ISO 6888-1 (2004): Mikrobiologija hrane i stočne hrane - Vodoravni postupak brojenja koagulazapozitivnih stafilokoka (Staphylococcus aureus i druge vrste), Hrvatski zavod za norme, Zagreb.

15. ISO Standard No. 5534 (2004): Cheese and Processed Cheese - Determination of the Total Solids Content (Reference Method). International Organization for Standardization, Geneva.

16. Ladero, V., Calles-Enríquez, M., Fernández, M., Alvarez, M.A. (2010a): Toxicological effects of dietary biogenic amines. Current Nutrition \& Food Science 6, 145-156. doi: dx.doi.org/10.2174/157340110791233256

17. Ladero, V., Fernández, M. Alvarez, M.A. (2009): Effect of post-ripening processing on the histamine and histamine-producing bacteria contents of different cheeses. International Dairy Journal 19, 759-762. doi: dx.doi.org/10.1016/j.idairyj.2009.05.010

18. Ladero, V., Fernández, M., Calles-Enríquez, M., Sánchez-Llana, E., Cañedo, E., Martín, M.C., Alvarez, M.A. (2012): Is the production of the biogenic amines tyramine and putrescine a species-level trait in enterococci? Food Microbiology 30, 132-138. doi: dx.doi.org/10.1016/j.fm.2011.12.016

19. Ladero, V., Martínez, N., Martín, Mc., Fernández, M. Alvarez, M.A. (2010b): qPCR for quantitative detection of tyramine-producing bacteria in dairy products. Food Research International 43, 289-295.

20. Lanciotti, R., Vannini, L., Patrignani, F., Iucci, L., Vallicelli, M., Ndagijimana, M., Guerzoni, M.E. (2006): Effect of high pressure homogenisation of milk on cheese yield and microbiology, lipolysis and proteolysis during ripening of Caciotta cheese. Journal of Dairy Research 73, 216-226. doi: dx.doi.org/10.1017/S0022029905001640
21. Linares, D.M., Martín, M.C., Ladero, V., Álvarez, M.A., Fernández, M. (2011): Biogenic amines in dairy products. CriticalReviewsinFoodScienceandNutrition 51,691-703. doi: dx.doi.org/10.1080/10408398.2011.582813

22. Martuscelli, M., Gardini, F., Torriani, S., Mastrocola, D., Serio, A., Chaves-Lopez, C., Schirone, M., Suzzi, G. (2005): Production of Biogenic amines during the ripening of Pecorino Abruzzese cheese. International Dairy Journal 15, 571-578. doi: dx.doi.org/10.1016/j.idairyj.2004.11.008

23. Moret, S., Conte, L.S., Spoto, E. (1996): Biogenic amines in cheese-Parameters affecting their analytical determination. Industrie Alimentari 35, 788-792.

24. Öner, Z., Gül Karahan, A., Aloğlu, H. (2006): Changes in the microbiological and chemical characteristics of an artisanal Turkish white cheese during ripening Original Research Article. LWT- Food Science and Technology 39, 449-454,

25. Petridis, K.D., Steinhart, H. (1996a): Biogenic amines in hard cheese production: 1. Factors influencing the biogenic amine content of the finished product using Emmental cheese as an example. Deutsche LebensmittelRundschau 92, 114-120.

26. Petridis, K.D., Steinhart, H. (1996b): Biogenic amines in hart cheese production. 2. Control points-study in a standardised swiss sheese production. Deutsche Lebensmittel-Rundschau 92, 142-146.

27. Radeljević, B., Mikulec, N., Antunac, N., Prpić, Z., Maletić, M., Havranek, J. (2013): Influence of starter culture on total free aminoacids concentration during ripening of Krk cheese. Mljekarstvo 63, 15-21.

28. StatSoft Inc STATISTICA (data analysis software system), version 10. 2011. StatSoft, Inc. Tulsa, OK.

29. Valsamaki, K., Michaelidou, A., Plycroniadou, A. (2000): Biogenic amine production in Feta cheese. Food Chemistry 71, 259-266. doi: dx.doi.org/10.1016/S0308-8146(00)00168-0 